\title{
KAJIAN POSTKOLONIAL DALAM NOVEL SALAH ASUHAN KARYA ABDOEL MOEIS
}

\author{
'Debby Sebtia Clara; ${ }^{2}$ Yayah Chanafiah; ${ }^{3}$ Emi Agustina \\ ${ }^{1,2,3}$ Program Studi Pendidikan Bahasa Indonesia FKIP Universitas Bengkulu
}

Abstrak

\section{Korespondensi: debbysebtiaclara_14@yahoo.com}

Penelitian ini membahas tentang Postkolonial dalam Novel Salah Asuhan Karya Abdoel Moeis. Metode yang digunakan dalam penelitian ini adalah metode deskriptif dengan pendekatan kualitatif. Teknik yang digunakan dalam pengumpulan data adalah teknik studi pustaka. Terdapat unsur-unsur di dalam teori Postkolonial yakni mimikri, hegemoni dan konsep barat-timur dimana tokoh dalam novel ini mengalami mimikri, hegemoni dan konsep barat-timur yang dilihat dari bagaimana gaya berbicara, berpakaian, bersikap, gaya hidup dan cara berpikirnya. Penelitian ini bertujuan untuk mengkaji novel Salah Asuhan Karya Abdoel Moeis dengan menggunakan teori postkolonial. Teknik analisis data yang digunakan analisis deskriptif kualitatif ini adalah membaca dan memahami novel, membuat sinopsis, mengidentifikasi, mengklasifikasi, menganalisis dan mengkaji, dan menarik kesimpulan. Hasil penelitian ini menunjukkan bahwa: (1) pemikiran yang terkonsep pada budaya Barat menjadikan seluruh aspek kehidupan Hanafi menjadi kebaratbaratan. (2) Mimikri yang dilakukan oleh tokoh Hanafi dilihat dari gaya hidup, bahasa, tingkah laku, sikap dan cara berpikir yang menjadi kebarat-baratan, dan (3) pemberontakan Hanafi terjadi karena adanya kekuasaan atau hegemoni pada budaya dan adat bangsa Timur.

Kata Kunci: postkolonial, konsep barat-timur, mimikri, dan hegemoni

\begin{abstract}
This study discusses Postcolonial in Novel "Salah Asuhan" by Abdoel Moeis. The method used in this research is descriptive method with a qualitative approach. The technique used in data collection is literature study technique. There are elements in Postcolonial theory, namely mimicry, hegemony and east-west concepts where the characters in this novel are going mimicry, hegemony and east-west concepts as seen from how they talk, the dress, behave, lifestyle and the way of thinking. This study aims to examine the novel "Salah Asuhan" by Abdoel Moeis by using postcolonial theory. Data analysis techniques used in this descriptive qualitative analysis are reading and understanding novels, making synopsis, identifying, classifying, analyzing and studying, and drawing conclusions. The results of this study indicate that: (1) thoughts conceptualized in Western culture make all aspects of Hanafi life Westernized. (2) Mimicry conducted by Hanafi figures viewed from the lifestyle, language, behavior, attitudes and the way of thinking become westernized, and (3) Hanafi rebellion occurs because there is a power or hegemony in Eastern cultures and customs.
\end{abstract}

Keywords: postcolonial, mimicry, hegemony and east-west concepts 


\section{PENDAHULUAN}

Indonesia merupakan negara yang dikenal sebagai negara penghasil rempah-rempah, karena tanah Indonesia sangat subur. Sehingga apapun yang ditanam akan tumbuh dan sumber daya alam yang sangat melimpah. Hal inilah yang membuat bangsa lain tertarik untuk menguasai bangsa Indonesia.

Keinginan untuk menguasai bangsa Indonesia inilah yang membuat negara ini dijajah oleh berbagai negara, baik negara Portugis, Spanyol, Belanda, Perancis, Inggris dan Jepang. Dari enam negara tersebut yang paling lama menjajah bangsa Indonesia adalah bangsa Belanda yaitu tiga ratus lima puluh tahun lamanya. Karena penjajahan ini membuat warga negara Indonesia tertekan dan tersiksa karena harus kerja paksa. Awalnya para wartawan serta sastrawan bisa bebas menyampaikan pendapat mereka namun karena mereka melakukan kritik terhadap sistem kolonial yang menindas dan memotret peristiwa yang terjadi di masa itu lewat berita yang mereka sampaikan dan bahkan lewat karya yang mereka buat, mereka tidak bebas lagi memberikan pendapat.

Karya sastra merupakan media ekspresi untuk mengungkapkan realitas kehidupan dan mengandung nilai-nilai yang ada di masyarakat. Nilai-nilai dalam masyarakat berupa nilai sosial, kehidupan, estetika, moral dan lainnya. Salah satu karya sastra adalah novel. Istilah novel berasal dari bahasa latin novellas yang kemudian diturunkan menjadi noveis, yang berarti baru. Perkataan baru ini dikaitkan dengan kenyataan bahwa novel merupakan jenis cerita fiksi yang muncul belakangan dibandingkan dengan cerita pendek dan roman (Waluyo,2002:36). Novel dapat dibagi menjadi dua golongan yaitu karya yang serius dan karya hiburan. Syarat utama novel adalah ceritanya mesti menarik, menghibur dan mendatangkan rasa puas setelah orang selesai membacanya. Novel yang baik adalah novel yang isinya dapat memanusiakan para pembacanya.

Secara tradisional, Nurgiyantoro membagi unsur-unsur pembangun novel menjadi dua, yaitu unsur ekstrinsik dan unsur intrinsik. Unsur ekstrinsik menurut Nurgiyantoro adalah unsur yang berada di luar karya fiksi yang mempengaruhi lahirnya karya namun tidak menjadi bagian di dalam karya fiksi itu sendiri. Sedangkan unsur intrinsik merupakan unsur pembangun karya sastra yang berasal dari dalam karya itu sendiri. Pada novel unsur intrinsik itu berupa tema, plot, penokohan, latar, sudut pandang, gaya bahasa, dan amanat (Nurgiyantoro, 2009:23).

Ada beberapa satrawan yang membuat suatu karya yang menceritakan tentang orang barat dan pribumi. Salah satunya Abdoel Moeis yang bergelar Soetan Penghoeloe, ayahnya berasal dari Minangkabau dan ibunya berasal dari tanah Jawa dan ia menjadi seorang penulis karena ingin melawan kebobrokkan Belanda (Ensiklopedia Kemendikbud) .

Karya sastra yang membuat Abdoel Moeis terkenal yaitu novel yang berjudul Salah Asuhan yang membicarakan tentang kolonialisme. Novel Salah Asuhan Karya Abdoel Moeis ini menceritakan kisah cinta seorang laki-laki pribumi dengan seorang wanita berdarah Belanda. Hanafi tinggal di keluarga Eropa dan sekolah di HBS, membuat Hanafi harus beradaptasi dengan lingkungan baru. Karena Hanafi bergaul dengan orangorang Eropa, sudut pandang Hanafi akan budaya Minangkabaupun berubah. Pemikiran Hanafi ini sudah terkonsep pada budaya Barat. Sehingga adanya pertentangan konsep antara Barat dan Timur. 
Dari sudut pandang yang terkonsep pada budaya barat ini, terlihat dari peniruan yang dilakukan oleh tokoh utama, dimana Hanafi banyak menirukan bangsa Barat seperti halnya cara berpakaiannya, berbicara bahkan sampai pada perabotan rumahnya.

Namun, meskipun Hanafi lebih menyukai budaya Barat, Hanafi tidak dapat melepaskan setiap adat dan budaya dari bangsa Timur. Hal inilah yang membuat Hanafi merasa tertekan. Hanafi harus mengikuti setiap aturan yang ada di Minangkabau.

Karena novel Salah Asuhan banyak membicarakan tentang penjajahan atau kolonialisme, maka peneliti mengambil teori postkolonial untuk dijadikan pisau bedah dalam penelitian ini. Dari kata postkolonial ini kita bisa menebak bahwa teori ini membahas tentang peristiwa sesudah kolonialisme atau era kemerdekaan dan bisa juga membahas dampak-dampak yang ditimbulkan setelah penjajahan. Kata postkolonial tidak hanya mengacu pada pengertian 'sesudah' kolonial atau era kemerdekaan, melainkan kondisi-kondisi yang ditinggalkannya, sejak awal terjadinya kolonialisasi dan dampakdampak yang ditimbulkannya (Ratna, 2008: 90).

Postkolonial ini membahas tentang konsep barat-timur, mimikri, dan hegemoni yang terdapat di dalam novel tersebut. Konsep barat-timur membahas tentang hubungan antara kebudayaan Barat dan kebudayaan Timur. Pada masa penjajahan Belanda muncullah istilah "inlander" untuk menyebutkan golongan pribumi. Pemakaian istilah tersebut berarti juga sebuah pemberian identitas dan juga menandakan adanya permasalahan ras dan etnisitas. Mimikri menurut Bhabha adalah sebuah strategi perubahan, peraturan, dan disiplin yang menyesuaikan diri dengan 'yang lain', karena mimikri merupakan visualisasi dari kekuatan kolonial (Yasa,2012:70,234). Hegemoni merupakan suatu kekuasaan atau dominasi atas nilai-nilai kehidupan, norma, maupun kebudayaan sekelompok masyarakat yang akhirnya berubah menjadi doktrin terhadap kelompok masyarakat lainnya dimana kelompok yang didominasinya secara sadar mengikutinya.

Berdasarkan latar belakang yang telah diuraikan maka peneliti bermaksud untuk melakukan penelitian berjudul "Kajian Postkolonial dalam Novel Salah Asuhan Karya Abdoel Moeis".

\section{METODE}

Metode yang digunakan dalam penelitian ini adalah metode deskriptif kualitatif. Dalam penelitian ini menggunakan pendekatan postkolonial. Sumber data penelitian ini adalah novel Salah Asuhan Karya Abdoel Moeis, terbitan Balai Pustaka, pada tahun 2009 cetakan ke-39 dengan tebal 273 halaman. Data penelitian ini berupa kata-kata, kalimat-kalimat atau ungkapan-ungkapan yang diperlukan dalam penelitian yang berhubungan dengan aspek gejala kultural, yaitu konsep barat-timur, mimikri, dan hegemoni. Teknik yang digunakan dalam pengumpulan data adalah teknik studi pustaka. Teknik analisis data yang digunakan analisis deskriptif kualitatif ini adalah membaca dan memahami novel, membuat sinopsis, mengidentifikasi, mengklasifikasi, menganalisis dan mengkaji, dan menarik kesimpulan.

\section{HASIL DAN PEMBAHASAN}

\section{Hasil}

Berdasarkan hasil penelitian yang dilakukan maka diperoleh hasil penelitian terdiri atas tiga aspek sebagai berikut: 


\section{Debby Sebtia Clara; Yayah Chanafiah; Emi Agustina}

1. Bentuk konsep barat-timur pada novel Salah Asuhan

2. Mimikri tokoh pribumi

3. Hegemoni antar tokoh

Berikut dijelaskan data yang telah didapat

\section{Pembahasan}

A. Konsep Barat-Timur

Konsep barat-timur membahas tentang hubungan antara kebudayaan Barat dan kebudayaan Timur. Pada masa penjajahan Belanda muncullah istilah "inlander" untuk menyebutkan golongan pribumi. Pemakaian istilah tersebut berarti juga sebuah pemberian identitas dan juga menandakan adanya permasalahan ras dan etnisitas (Yasa,2012: 70)

Dalam novel Salah Asuhan, konsep barat-timur menceritakan tokoh Hanafi sebagai tokoh yang mana pemikirannya sudah terkonsep pada budaya Barat karena pergaulannya dengan orang-orang Eropa. "Jadi dengan tidak berpikir panjang anak anda sudah memasukkan surat berhenti bersama ini, sedang sementara menanti angkatan, sudah empat belas hari lamanya anak anda bekerja sebagai 'maandgelder' di kantor BB" (Salah Asuhan, 2009: 132).

Hanafi lebih memilih bekerja dengan orang-orang kalangan Eropa dengan penghasilan yang lebih sedikit dari pada bekerja dengan orang-orang Minangkabau yang penghasilannya cukup untuk kebutuhannya. Hal ini dikarenakan pandangan akan budaya Barat itu sendiri dimana menurutnya bekerja dengan orang-orang Eropa lebih bergengsi.

Dibudaya Timur masih kuat dengan kawin paksa dengan kerabat dekat, sedangkan budaya Barat membebaskan setiap orang dalam memilih pasangannya tidak dipilihkan oleh keluarga. Hal inilah yang membuat Hanafi lebih tertarik akan budaya Barat daripada budaya Timur. Budaya Barat memang memiliki daya tarik yang luar biasa, pasalnya Barat tidak memiliki banyak aturan hidup di dalamnya. Hal inilah yang membuat banyak orang tertarik akan kebebasan yang ditawarkan oleh budaya Barat tersebut. Dilihat dalam kutipan di bawah ini:

"Itulah yang kusegankan benar hidup di tanah Minangkabau ini, Bu, di sini semua orang berkuasa, kepada semua orang kita berutang, baik utang uang maupun utang budi. Hati semua orang mesti dipelihara dan laki-laki perempuan itu dipergaduh-gaduhkan dari luar buat menjadi suami istri. Itulah yang menarik hatiku pada adat orang Belanda. Pada kecilnya yang menjadi keluarganya hanyalah; ayah-bundanya, adik-kakaknya. Setelah ia besar, dipilihnya sendiri buat istrinya; dan ayah-bundanya, apalagi mamak bilainya atau 'tua-tua di dalam kampung 'harus menerima saja pilihannya itu jika tidak berkenan-boleh menjauh! Dan setelah beristri, bagi orang itu yang menjadi keluarga ialah, istrinya dan anak-anaknya saja. Tapi kita di sini kebatmengebat, takluk-menaklukkan, tanya-menanya dengan tidak ada hingganya. Sebelum beristri, dalam beristri, hendak bercerai, tidak putus-putuslah kita dari pencampuran orang-orang lain yang belum tentu berhati tulus kepada kita” (Salah Asuhan, 2009: 31). 
Timur memiliki budaya dimana harus membalas kebaikan hati dari orang lain. Begitulah yang terjadi pada Hanafi, meski ia mampu membayar hutang uang dengan gajinya per bulan namun hutang budinya tetaplah harus dibayar dengan budi. Sehingga orang yang akan menerima utang budi tersebut memiliki hak atas orang yang akan membalas hutang budi tersebut. Terlihat dalam kutipan di bawah ini:

“... Selama aku sekolah, mamakku turut-turut menunjang belanjaku itu dengan uang, dengan tidak setahuku. Dengan tidak setahuku pula, ibuku sudah menggadaikan aku pada mamak itu, artinya setamat aku sekolah, buat membayar utangku itu, Engku Sutan Batuah ada hak buat mengambil aku menjadi menantunya..." (Salah Asuhan, 2009: 112).

Itulah yang menjadi alasan Hanafi untuk menerima permintaan ibunya, karena ia tidak dapat menolaknya. Ia menerima bukan karena menyukainya tetapi ia tidak dapat membantah perkataan ibunya dikarenakan pada saat itu Hanafi baru sembuh dari sakitnya sehingga pikirannya tidak dapat berpikir secara jernih dan pada akhirnya ia menerima saja apa yang dikatakan ibunya.

Ketertarikan Hanafi akan budaya Barat mengubah segala aspek baik gaya hidup, pola pikir, sikap, pendidikan, ekonomi dan lain sebagainya. Sehingga pada saat pernikahannya dengan Rapiah, Hanafi ingin pernikahannya menggunakan adat Barat yang tidak begitu menyulitkan untuk dirinya. Seperti halnya pakaian, dalam pernikahan adat minang tentu mereka memiliki pakaian adat yang dikenakan saat perhelatan, namun menurut Hanafi itu sangat kuno. Ia lebih suka menggunakan kemeja, jas, dasi, dan sepatu layaknya orang Barat melaksanakan pernikahan. Terlihat dalam kutipan berikut ini, “...,bahwa ia memakai 'smoking' yaitu jas hitam, celana hitam dengan berompi dan berdasi putih..." (Salah Asuhan, 2009: 73). Tentu saja itu sudah menyalahi aturan adat di Minangkabau, namun jika tidak dituruti akan lebih malu lagi karena pernikahan akan dibatalkan oleh Hanafi.

Pernikahan pun akhirnya terlaksana. Namun, rumah tangga Hanafi dengan Rapiah tidak harmonis. Pasalnya pernikahan mereka tidak didasari cinta namun pernikahan ini karena suatu keterpaksaan. Sehingga pada akhirnya mereka bercerai, setelah perceraian mereka Hanafi menikahi gadis Eropa yang bernama Corrie. Namun sebelum Hanafi menikahi Corrie, Hanafi sudah berpindah kewarganegaraan. Perpindahan bangsa yang dilakukan oleh Hanafi ditegaskan lagi dalam surat yang ia kirimkan kepada ibunya. Terlihat dalam kutipan di bawah ini:

"Bunda! Dengan persamaan kepada bangsa Belanda itu anak anda seolaholah sudah keluar dari bangsa dan dari 'payung' kita. Katakanlah kepada orang-orang di kampung bahwa gelarku 'Sutan Pamenan' sudah kuletakkan dan hendaklah mereka mengisarkannya kepada yang lain. di dalam segala 'hitungan di kampung' anak anda tak usah dibawa-bawa lagi, karena dengan rela hati anakan da sudah keluar dari adat dan dari bangsa. Hanya satulah yang tidak akan putus, yaitu antara anak anda dengan ibu, tentu tidak akan berubahubah keadaannya" (Salah Asuhan, 2009: 134).

Dan pada akhirnya, rumah tangga Hanafi dan Corrie juga tidak harmonis. 
Dan akhirnya mereka pun berpisah. Setelah itu ajalpun menjemput mereka. Jenazah Hanafi ditolak oleh warga Minangkabau dikarenakan Hanafi sudah keluar dari bangsa Timur.

B. Mimikri

Hanafi merasa bahwa dirinya sudah menjadi bagian dari bangsa Barat, meski dia hanya bisa menggunakan bahasa Belanda. Ia mulai tidak lagi menghargai adat budaya Timur yang merupakan leluhurnya. Hanafi menganggap bahwa hanya orang-orang dari bangsa Baratlah yang sederajat dengannya, sehingga sanak keluarganya dipandangnya tidak sederajat dengan dirinya. Menurutnya dengan berbahasa Belanda orang akan memiliki derajat yang lebih tinggi. Hanafi memandang bahasa pribumi sebagai bahasa yang lama dan kuno atau bahasa mati, sedangkan bahasa Belanda adalah bahasa yang modern dan sebagai bahasa ilmu pengetahuan. Dinyatakan dalam kutipan di bawah ini:

“...Anak-anak itu tahu abc, pandai sedikit-sedikit berbahasa Belanda, disangka orang mereka sudah ada di puncak gunung kepandaian. Tapi pengetahuan umum, yang dikatakan orang Belanda algemene ontwik.keling itu semua hanya didapat di HBS saja dan kalau lama bercampur gaul atau tinggal di rumah orang Belanda” (Salah Asuhan, 2009: 32).

Hanafi tidak hanya menirukan bahasa Belanda saja tetapi juga menirukan identitas yang dimiliki oleh orang Belanda, berikut kutipan yang menggambarkan pernyataan tersebut:

"maka tiadalah ia segan-segan mengeluarkan uang buat mengisi rumah sewaan di Solok itu secara yang dikehendaki oleh anaknya. Hanafi berkata, bahwa ia dari kecilnya hidup di dalam rumah orang Belanda saja, jadi tidak senanglah hatinya, jika aturan mengisi rumahnya tidak mengarah-arah itu pula" (Salah Asuhan, 2009: 24).

Dalam bergaul dan berbahasa dengan menggunakan bahasa Belanda bahkan pakaian serta tingkah lakunya menjadi kebarat-baratan, menurutnya hal itu sangatlah masuk akal sesuai dengan perkembangan zaman yang semakin modern. Sikap dan perilakunya itu ditunjukkannya juga ketika ia menikahi gadis pilihan ibunya itu, mulai dari adat, pakaian, dan kebiasaan haruslah menggunakan cara orang Belanda ketika menikah. Berikut kutipan yang menggambarkan pernyataan tersebut:

“... Di dalam peralatan itu hampir-hampir pernikahan itu dibatalkan, karena timbul perselisihan antara pihak kaum perempuan dengan kaum laki-laki. Pangkalnya dari Hanafi juga. Ia berkata "kaum muda". Pakaian mempelai secara yang masih dilazimkan sekarang dinegerinya, yaitu pakaian secara zaman dahulu, disebutkannya "anak komidi Stambul". Jika ia dipaksa memakai secara itu, sukalah ia urung saja, demikian katanya dengan pendek. Setelah timbul pertengkaran di dalam keluarga pihaknya sendiri akhirnya diterimalah, bahwa ia memakai "smoking" yaitu jas hitam, celana hitam 
dengan berompi dan berdasi putih. Tapi waktu hendak menutup kepalanya sudah berselisih pula. Dengan kekerasan ia menolak pakaian destar saluk, yaitu pakaian orang Minangkabau. Bertangisan sekalian perempuan, meminta supaya ia jangan menolak tanda keminangkabauan yang satu itu, yaitu selama beralat saja. Jika peralatan sudah selesai, bolehlah ia memakai sekehendak hatinya pula" (Salah Asuhan, 2009: 73).

Pernikahan yang dilakukan Hanafi dengan Rapiah ini menimbulkan berbagai pertentangan dari keluarga, pasalnya hanafi ingin adat, pakaian hingga alat-alat yang digunakan haruslah sesuai dengan cara orang Belanda. Bukan hanya pengantin pria saja, namun pengantin wanita juga haruslah sesuai dengannya. Hal ini ditunjukkan dalam kutipan di bawah ini:

“... Belum puas Hanafi bertingkah dengan pakaiannya sendiri, ke pihak perempuan ia ada pula menyampaikan permintaan, supaya pengantin perempuan jangn pula 'digilakan' dengan 'anak joget' yang berumbai-rumbai itu, melainkan dimintanya supaya pengantin perempuan itu ke luar dengan pakaian sederhana saja, yaitu berbaju pendek gunting priangan, sedang sanggul rambutnya tidak boleh dihiasi sesuatu apa,lain dari pada sisir hiasan dan kulit penyu atau sesuatu tusuk kundai yang amat sederhana saja" (Salah Asuhan, 2009:74).

Cara-cara dan adat dalam pernikahannya itu haruslah sederajat dengannya. Pakaian dan cara pernikahannya ini mendapatkan banyak pertikaian dari pihak pengantin perempuan, pasalnya mereka harus mengikuti cara adat pernikahan orang Barat yang diterapkan Hanafi. Tokoh Hanafi menirukan adat dan lembaga bangsa lain dan menerapkannya ke segala kehidupan yang dijalaninya itu.

Karena pergaulan Hanafi tidak terlepas dari orang-orang Belanda dan Eropa, membuat pemikiran dan tingkah lakunya mulai terkonsep pada budaya Barat dan berambisi untuk sejajar dengan Bangsa Barat. Pemikiran yang terkonsep akan budaya Barat inilah yang menjadikan Hanafi banyak menirukan budaya-budaya barat seperti yang sudah dijelaskan di atas.

C. Hegemoni

Timur memiliki budaya dimana orang yang lebih tua harus dihargai dan dihormati. Timur lebih terkenal dengan adat yang menjadi patokan hidup bagi masyarakat yang ada, yang mana kelompok Timur harus mengikuti aturan adat yang ada di daerahnya tersebut. Dilihat dalam kutipan ini, "Mamakmu guru kepala, Hanafi, secara kami orang kampung, sudah sampai pandailah namanya orang serupa itu" (Salah Asuhan, 2009: 30).

Pemimpin dalam masyarakat adat Minangkabau disebut "penghulu" dengan panggilan sehari-hari "datuak", karena tugasnya secara keseluruhan disebut "niniek mamak" dan segala staf pembantunya disebut "pemangku adat". Hal ini menjelaskan bahwa, niniek mamak merupakan orang yang sangat penting dalam adat di Minangkabau. Untuk itu, kutipan di atas ini menyatakan bahwa setiap masyarakat di Minangkabau haruslah menghormati dan menghargai keberadaan niniek mamak. 
Kutipan ini menguatkan penjelasan di atas, "Baiklah, Hanafi, pandai tak pandai mamakmu itu, tapi orang kampung secara ibu pula; menurut galib di kampung engkau harus di bawah perintahnya"(Salah Asuhan, 2009: 30).

Minangkabau merupakan satu-satunya suku yang menganut sistem matrilineal di negara Indonesia. Matrilineal itu sendiri merupakan suatu adat masyarakat yang mengatur alur keturunan berasal dari pihak ibu. Jadi, selain niniek mamak mengatur setiap aturan dalam keluarga besarnya, ibu juga memiliki peran penting untuk menentukan jalan hidup atau jodoh anaknya pada masa itu. Seperti yang terjadi pada Hanafi, ibu Hanafi memaksa anaknya untuk melunasi hutang budi itu dengan cara menjadikan Rapiah istrinya. Terlihat dalam kutipan di bawah ini:

“...Meskipun kau angsur beratus atau beribu rupiah, sampai langsai utang itu, belumlah akan selesai utang piutang karena utang budimu harus kau bayar dengan budi pula... Utang itu pun dimaksudkan tidak akan mrnjadi utang uang, tetapi ia mengharapkan dan menantikan engkau buat anaknya yang seorang itu saja; buat Rapiah" (Salah Asuhan, 2009:30).

Ketidakberdayaan Hanafi melihat ibunya memukuli dirinya sendiri membuat ia harus menuruti permintaan ibunya itu. Dinyatakan dalam kutipan di bawah ini: "Setelah ibunya sendiri hilang sabarnya dan memukul-mukul dada di muka anak yang 'terpelajar' itu, barulah Hanafi menurutkan kehendak orang banyak, sambil mengeluh dan teringan akan badannya yang sudah ... 'tergadai”' (Salah Asuhan, 2009:73).

Kutipan tersebut menyatakan bahwa Hanafi merasa dirinya sudah digadaikan oleh ibunya. Dan setelah menikah, Hanafi memandang Rapiah merupakan seorang istri yang diberikan olehnya. Sehingga perlakuan Hanafi kepada rapiah tidaklah seperti layaknya suami dan istri, bahkan Hanafi bukan lagi melihat Rapiah sebagai istri melainkan sebagai 'babu' yang diberikan ibunya kepada dirinya. Dan kutipan ini memperkuat penjelasan di atas, " Hanafi makin lalu-lalang kepada Rapiah, yang akhirnya dipandangnya bukan lagi 'istri' melainkan 'babu' yang diberikan kepadanya dengan paksa” (Salah Asuhan, 2009:81)

Karena kuatnya budaya dan adat Minangkabau, membuat Hanafi merasa terkekang. Sehingga ia berusaha memberontak lewat perlakuannya terhadap istrinya, Rapiah. Ketika mencemooh dan memaki istrinya serta menyalahi ibunya, Hanafi merasakan adanya kepuasan akan dirinya karena sudah meluapkan setiap kekecewaan dan amarah yang ia rasakan selama ini. Bahkan perlawanan yang membuat ibu Hanafi enggan lagi untuk mengakui anaknya adalah pernikahan Hanafi dengan gadis Belanda yang bernama Corry Du Busse dan menceraikan Rapiah menggunakan surat pengadilan yang ia kirimkan. Dinyatakan dalam kutipan berikut, "Surat keputusan" (Salah Asuhan, 2009: 135). Setelah mengetahui bahwa Hanafi mengirimkan surat dari pengadilan membuat hati Rapiah dan ibu Hanafi hancur dan hanya air mata yang terus mengalir, kata tak lagi mampu terucapkan. Kutipan ini menguatkan penjelasan tersebut, "Sejurus lamanya kedua perempuan itu berpandang-pandangan dengan tidak berkata sepatah jua. Hanya air mata mereka saja yang jatuh bercucuran" (Salah Asuhan, 2009: 135).

Tentu saja hal ini membuat kesedihan yang sangat mendalam bagi ibu Hanafi. Segala hal ia telah lakukan untuk anaknya namun Hanafi tidak memedulikan perasaan 
ibunya. Sakit hati dan kecewa yang sangat teramat dirasakan oleh ibu Hanafi, baginya ketika Hanafi memilih meninggalkan status kebumiputraannya, Hanafi juga sudah memutuskan hubungan dengan ibunya serta hubungan silaturahmi dengan ibunya.

Karena merasa terkekang, Hanafi berusaha keluar dari budaya Timur. dan pada akhirnya, Hanafi memilih untuk berpindah kewarganegaraan.

\section{PENUTUP}

Berdasarkan hasil penelitian postkolonial dalam novel Salah Asuhan ini kesimpulannya adalah dimana Hanafi bergaul dengan orang-orang Barat sehingga pemikirannya sudah terkonsep pada budaya Barat. Hal ini menyebabkan Hanafi merasa tertekan akan budaya Timur karena ia sudah terbiasa akan budaya Barat. Pada akhirnya ia pun melakukan penolakan akan setiap aturan budaya Timur.

Pemikiran yang terkonsep pada budaya Barat ini terlihat pada peniruan yang dilakukan Hanafi pada budaya Barat tersebut. Mimikri yang dilakukan oleh tokoh Hanafi dapat dilihat dari gaya hidup, bahasa, tingkah laku dan cara berpikir yang menjadi kebaratbaratan hal ini dipengaruhi oleh lingkungan sosialnya yang notabene orang-orang Eropa. Peniruan inilah yang menjadi bukti nyata bahwa kehidupan Hanafi sudah terkonsep pada budaya Barat.

Pada tokoh Hanafi yang menghegemoni atau yang berkuasa adalah adat dan budaya bangsa Timur, sehingga membuat dirinya tidak kuasa untuk melawan budaya tersebut. Karena kekuasaan yang berlaku pada bangsa Timur, pribadi Hanafi menjadi keras dan suka memberontak hal ini merupakan sikap penolakannya terhadap budaya tersebut.

Disarankan pada penelitian selanjutnya untuk melanjutkan telaah pada novel ini pada unsur ambivalensi, diaspora dan orientalisme..

\section{DAFTAR RUJUKAN}

Moeis, Abdoel. 2009. Salah Asuban. Jakarta: Balai Pustaka.

Nurgiyantoro, Burhan.(2009). Teori Pengkajian Fiksi. Yogyakarta: Gajah Mada University Press.

Ratna, Nyoman Kutha. 2008. Postkolonialisme Indonesia Relevansi Sastra. Yogyakarta: Pustaka Pelajar

Waluyo, Herman J. (2002). Pengkajian Prosa Fiksi. Surakarta: UNS Press.

Yasa, I Nyoman. (2012). Teori Sastra dan Penerapannya. Bandung: Karya Putra Darwati. 